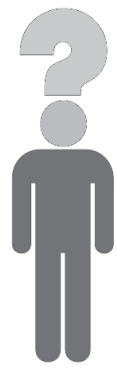

Barbara Hartman

\title{
ODPOWIEDZIALNOŚĆ - WOKÓŁ KONCEPCJI PAULA RICCEURA
}

By wstępnie zorientować się w historycznym dziedzictwie refleksji nad odpowiedzialnością, warto zacząć od starego i bezcennego źródła historycznego, od jednego z fundamentów naszej kultury europejskiej i wiecznie żywego przekaźnika idei moralnych, jakim jest Biblia ${ }^{1}$. Stary Testament w wielu miejscach mówi o odpowiedzialności - w swoistym i zapewne nie całkiem przystającym do nowożytnego jej pojmowania znaczeniu. Porządkując konteksty używania tego pojęcia, można wyróżnić kategorie:

1. Brania na siebie odpowiedzialności w postaci wzięcia kogoś pod swoją opiekę i stania się odpowiedzialnym za jego dalsze życie ( $R d z 44,32)$.

2. Odpowiedzialności za cudze czyny w postaci:

a) ponoszenia kary za zbrodnie wynikłe z decyzji władzy (władcy), co wyrażone jest klątwą i życzeniem - na przykład „Niech odpowiedzialność spadnie na głowę Joba i na cały jego ród " (Sm 3, 29);

b) przekonania o złożeniu przez Boga odpowiedzialności na głowę władcy za cudze złe czyny, mówi się na przykład: „Na ciebie Pan zrzucił odpowiedzialność za krew rodziny Saula, w miejsce którego zostałeś królem” (Sm 16, 8);

c) przekonania o istnieniu fatum i nieuchronności cierpienia za winy przodków, co zwalnia z dbania o własny wizerunek moralny i z odpowiedzialności za czyny i za decyzje. Takie przekonania przedstawia się tam jako tymczasowe i domagające się zmiany, bo odpowiedzialność powinna być tylko osobista (Jr 31, 27-30).

3. Podkreślania nadrzędności odpowiedzialności osobistej w stosunku do zbiorowej, co można zegzemplifikować następująco:

a) „a odpowiedzialność za krew jego spadnie na niego samego” (Ez 18, 13);

1 Biblia Tysiąclecia, Poznań 2003. Cytowania poniżej odnoszą się do tego wydania. 
b) „odpowiedzialność za czyny twoje spadnie na twoją głowę” (Ab 1, 15);

c) "to na ich głowy składam odpowiedzialność za ich postępowanie" (Ez 11, 12).

d) „aby cię osądzić według twoich dróg i ciebie uczyni odpowiedzialną za wszystkie twoje obrzydliwości. Oko moje nie okaże litości dla ciebie i nie pominę cię, ale ciebie uczynię odpowiedzialną za twoje drogi, a twoje obrzydliwości będą pośród ciebie [ujawnione] i poznacie, że Ja jestem Pan" (Ez 7, 3-4).

4. Podkreślania nadrzędności odpowiedzialności osobistej, a nie dziedziczonej, co tłumaczy się tym, że człowiek nie może ponosić odpowiedzialności za czyny swoich poprzedników i przodków (Ez 18).

5. Zwalniania z odpowiedzialności - występuje zazwyczaj w prośbach do Boga w imię powoływania się na sprawiedliwość.

6. Funkcjonowania odpowiedzialności - tu podkreśla się rolę odpowiedzialności w utrzymaniu więzi społecznych i międzypokoleniowych (Rdz 18, 22).

W naszej tradycji, wywodzącej się z duchowości biblijnej, staro- i nowotestamentowej, odpowiedzialność przynależy do natury człowieka. W bardziej archaicznym jej rozumieniu jest odpowiedzialnością przed Bogiem i panem, a później, w miarę wzrostu kultury prawnej, stawała się kategorią prawną, blisko związaną z pojęciem winy, a także z pojęciem obywatelstwa, civitas. Od czasów greckich i rzymskich odpowiedzialność jest podstawą oraz pożądanym przejawem działania świadomego obywatela, dbającego o dobro swoje, jak i dobro wspólne. Nie będzie chyba zbyteczne dodać, że w sensie ogólnym cechuje ona postawę człowieka cnotliwego.

Z odpowiedzialnością blisko związane jest pojęcie obowiązku. Ma się wtedy na myśli zobowiązanie do wykonania jakiegoś czynu albo zobowiązanie do niewykonywania (poniechania) go. Odpowiedzialność jako zobowiązanie jest pojęciem specyficznie etycznym i jako takie staje w centrum etyki Kanta².

O wadze odpowiedzialności w życiu mówi też klasyka literatury pięknej. "Stajesz się odpowiedzialny na zawsze za to, co oswoiłeś" - dowiaduje się Mały Książę ${ }^{3}$. Tylko pozornie dotyczy to relacji człowieka z rzeczą - różą - bo głębia tego nakazu jest przejmująca swym wielopłaszczyznowym zakresem skojarzeń i porównań. Człowiek jest tu ujmowany wraz ze swymi przeszłymi relacjami, ze swymi uczuciami i emocjami. Zrodził zaufanie do innych ludzi i wiarę, któ-

2 Zob. I. Kant, Uzasadnienie metafizyki moralności, tłum. M. Wartenberg, Warszawa 1984, s. 62-64.

3 A. de Saint-Exupéry, Mały ksiq̨żę, tłum. M. Cywińska, Białystok 1993, s. 50. 
ra trwa nadal. Zaniechanie dalszej troski nad różą, dalszych powinności (choćby nawet w sensie braku zainteresowania), czy to w stosunku do róży, czy do zwierzęcia, czy do innego człowieka, spowoduje stratę. Inaczej mówiąc, przemiana nieobojętnej odpowiedzialności w brak zainteresowania, czyli w obojętność, skutkuje krzywdą i winą.

Dotykamy tu jak gdyby naznaczenia człowieka. Naznaczenie to jest niezbywalne. Na każdym człowieku bowiem i na wszystkich ludzi nałożony jest ciężar odpowiedzialności za wszystkie swoje czyny już dokonane i za powzięte zamierzenia. I chodzi tu zarówno o czyny w stosunku do ludzi, jak i otoczenia (przyrody). Już samo istnienie u człowieka sumienia jest odzwierciedleniem noszenia życiowego brzemienia odpowiedzialności.

Ten aktywny aspekt rozumienia pojęcia odpowiedzialności należy uzupełnić znaczeniem „biernym”. Rozumiemy przez to czyny świadome, ale prowadzące do niechcianych strat i krzywd, czyli do niezamierzonych negatywnych konsekwencji. Do owego „biernego” rozumienia zaliczyłabym też zaniechanie oraz niedbałość.

Problem odpowiedzialności rozważany jest oczywiście od dawna w bardziej wymiernych aspektach niż w dziedzinie moralności, a mianowicie w prawodawstwie i w naukach prawnych. Jest on tam kluczowy, a pojęcie odpowiedzialności prawnej jest już od czasów prawa rzymskiego ważną kategorią karną i cywilną. Zagadnienie odpowiedzialności dotyczy tu na przykład tego, od kiedy, tzn. od jakiego wieku dokładnie, człowiek ponosi odpowiedzialność za swoje czyny, czym jest poczytalność i co może ją ograniczyć, wyłączając w całości lub w części odpowiedzialność.

Wydaje się nam, że reguły prawne nie powinny być dogmatyczne, lecz muszą być wrażliwe na procesy zmian i nieustannie się udoskonalać i dopasowywać do szybko zachodzących zmian społecznych, gospodarczych i politycznych w świecie.

Różne prądy teoretyczne w jurysprudencji zaczęły się rozwijać szczególnie po Wielkiej Rewolucji Francuskiej. Dziś mamy teorie analityczne języka prawniczego, teologiczne wykładnie prawa, filozofię i socjologię prawa o nachyleniu prawno-naturalnym bądź pozytywistycznym.

Herbert Hart (1998), sławny filozof prawa, uważa, że prawo nie może funkcjonować w sposób czysto pozytywistyczny (w myśl zasady, że normą prawa jest po prostu to, co za takową zostało ogłoszone), ale że pomiędzy moralnością, pozytywizmem, prawem naturalnym (trwałymi normami obyczaju) a autentycz- 
nym funkcjonowaniem pojęć prawnych w danym języku muszą być równowaga i kompromis. Hart zwraca uwagę na kilka ważnych i problemów w prawoznawstwie, jak usuwanie wady niepewności oraz wady nieskuteczności. Uważa także, że reguły prawne to jedna część systemu prawnego, a (odpowiedzialny) sędzia - jako wolny człowiek - to druga jego część; obie muszą być ze sobą w harmonii ${ }^{4}$. $Z$ tego powodu należy zawsze dopuszczać możliwość wielu prawidłowych rozstrzygnięć jednej i tej samej sprawy.

Gdybyśmy rozważania na temat problemu odpowiedzialności przeprowadzali tylko w ramach teorii prawa naturalnego, to pole problematyki zawęziłoby się do możliwych granic uznania stanu rzeczy. To, co naturalne, wymaga usankcjonowania przez prawo. Wtedy lex naturalis jest odbiciem lex aeterna (św. Tomasz, św. Augustyn). Jednak nowożytność przynosi rozwój teorii umowy społecznej i imperatywu kategorycznego (Thomas Hobbes, Jean-Jacques Rousseau, Immanuel Kant), a i wspomniany już pozytywizm (Austin, Hart) udoskonala pojęcie prawa i związki prawa z innymi sferami działalności człowieka. Współczesny psychologiczny i socjologiczny realizm prawniczy opiera się na postulacie pojmowania prawa jako rzeczywistości faktów psychicznych (Leon Petrażycki) i socjologicznych. Pojęcie odpowiedzialności w różnych kontekstach konkurujących ze sobą teorii prawa ulega znacznemu rozciągnięciu: odpowiedzialność jako odpowiedzialność przez Bogiem, odpowiedzialność jako konieczność poniesienia konsekwencji kolizji z prawem stanowionym, odpowiedzialność jako zobowiązanie i jako wina. Rozważanie problemu odpowiedzialności na płaszczyźnie prawa jest zadaniem złożonym, wieloaspektowym, trudnym i odpowiedzialnym.

Temat ontycznych podstaw odpowiedzialności podejmuje Roman Ingarden ${ }^{5}$ i widząc pomiędzy nimi istotne różnice, związki i konsekwencje, odróżnia cztery odmienne sytuacje ${ }^{6}$, w których można stwierdzić zachodzenie odpowiedzialności:

- pierwszą z nich jest ponoszenie odpowiedzialności za coś;

- drugą jest bycie pociąganym do odpowiedzialności;

- trzecia sytuacja to jest podejmowanie odpowiedzialności za coś;

- czwarta jest taka, że ktoś działa odpowiedzialnie;

\footnotetext{
Zob. H. Hart, Pojęcie prawa, tłum. J. Woleński, Warszawa 1998.

R. Ingarden, Ksiq̨żeczka o człowieku, Kraków 1987.

6 Wydaje mi się, że wyróżnione kategorie odpowiedzialności Ingardena nasuwają analogie ze Starym Testamentem.
} 
Zastanówmy się nad pierwszym z wymienionych rodzajów odpowiedzialności, czyli nad tym, co może oznaczać taki stan rzeczy i do jakiego czasu się on odnosi. Ingarden twierdzi, że jeżeli ktoś podejmie się wykonać zadanie i prawidłowo je wykona, to nie oznacza to końca jego odpowiedzialności za ten dokonany już w przeszłości czyn. Następuje bowiem „ciążenie” odpowiedzialności na sprawcy czynu i utrzymuje się ono w taki sposób, że nawet $w$ danej perspektywie czasowej i przy jednoczesnym trwaniu różnych przewidywalnych i nieprzewidywalnych następstw i skutków minionego czynu odpowiedzialność ta nie wygasa, ale trwa nadal. Nazwijmy ją brzemieniem. Człowiek świadomie i racjonalnie, a także w sposób wolny podejmuje nieustannie decyzje i czyny, za które jest odpowiedzialny bezterminowo. Nosi brzemię odpowiedzialności za to, co uczynit, i za skutki swoich czynów i zaniechań.

Zgodnie z takim rozumowaniem można by właściwie powiedzieć, że permanentna odpowiedzialność człowieka za swoje konkretne działania wydłuża się i przenosi na następstwa i konsekwencje tych działań. Powstaje pytanie o kres odpowiedzialności. Czy i kiedy się ona kończy? Czy śmierć sprawcy jest końcem jego odpowiedzialności za czyny? Czy jest możliwa sytuacja, że choroba lub niedomaganie zwalnia z odpowiedzialności za własne czyny? Jest możliwe także pytanie o poziom odpowiedzialności po zmianie zasadniczej roli życiowej, zawodowej lub społecznej. Pytania te nie byłyby chyba kompletne, gdybyśmy nie zapytali o jeszcze inny problem dotyczący ponoszenia odpowiedzialności - a mianowicie, czy można ją umniejszyć lub zrehabilitować innym czynem? Pytanie te dotyczą nie tylko etyki, lecz również prawodawstwa i sądownictwa.

Zwróćmy uwagę na trzeci wymieniony rodzaj odpowiedzialności: istnienie odpowiedzialności w sensie dobrowolnego uznania obciążenia siebie skutkami swoich działań. Inaczej mówiąc: co oznacza podejmowanie odpowiedzialności? Ingarden uważa, że

wzięcie odpowiedzialności przez sprawcę wychodzi wyraźnie na jaw szczególnie wtedy, gdy wynik jego czynu polega na zrealizowaniu jakiejś pozytywnej wartości, którą inni ludzie kwestionują albo podają za wartość negatywną i której sprawca ma nie przekreślać, lecz utrzymywać $i$ bronić. W tym wypadku wzięcie odpowiedzialności przybiera postać ręczenia sprawcy za tę wartość, a także za uprawnienie swego czynu?.

\footnotetext{
7 R. Ingarden, Ksiq̨żeczka o człowieku, dz. cyt., s. 94.
} 
Wydaje się, że do istoty odpowiedzialności przynależy również potencjalność zamierzenia działania - odpowiadamy za czyny dobrowolne i takie, które spełniliśmy, nie kontrolując ich, choć powinniśmy je kontrolować. W tym miejscu można spróbować zbudować wstępną, użyteczną w tym temacie, definicję odpowiedzialności, a mianowicie, że jest to uznanie konsekwencji podjętego już działania oraz następstw jego podjęcia, a także uznanie następstw jego niepodjęcia.

Człowiek jest ograniczony w swych możliwościach i strukturze, ale „jeśli wtedy zostawia wszystko; niech się dzieje, co chce, to działa nieodpowiedzialnie, ale właśnie dlatego staje się odpowiedzialny za taki sposób działania"8.

\section{Odpowiedzialność w ujęciu Paula Ricœura}

Paul Ricœur w swojej książce Filozofia osoby ${ }^{9}$ mówi o słabości ludzkich działań publicznych i pokazuje wzajemną zależność między odpowiedzialnością i słabością. O zależności tej mówi, że jest to stale utrzymująca się wzajemna relacja. Zależność ta przyjmuje często cechy tragizmu. Dlatego też, jak mówi Ricœur, „słabość ludzkich działań publicznych - mimo wyraźnych wspólnych cech, o których powinno się pamiętać - należy odróżnić od tego, co tragiczne za pomocą wewnętrznej relacji między słabością i odpowiedzialnością". Analiza zjawiska słabości dotyczy tu nie tyle zwykłego działania ludzkiego, ale działalności szerokiej, doniosłej, politycznej, nazywanej tu publiczną. Pomijając sytuację słabości jako tragizmu, zauważyć trzeba, że słabość rodzi wezwanie do działania w imię odpowiedzialności. Ricœur powołuje się na Hansa Jonasa (Prinzip Verantwortung - zasada odpowiedzialności) i mówi, że idea odpowiedzialności przybiera czasami formę zasady, a dzieje się to dzięki uczuciu. Uczucie jest tutaj nakazem do podjęcia działania. „Czujemy się powołani, wzywani przez to, co słabe w wielorakich zresztą kształtach, [...] do zrobienia czegoś, [...] do udzielenia pomocy, ale najbardziej do powodowania rozwoju, do pozwalania na spełnienie i rozkwit"10. Poprzez rodzące się w nas uczucie wobec słabego zaczynamy się czuć wobec niego odpowiedzialni. Inaczej mówiąc, to, co słabe, czyni nas za nie odpowiedzialnym. Powstaje sy-

8 Tamże, s. 96.

9 P. Ricœur, Filozofia osoby, tłum. M. Frankiewicz, Kraków 1992.

10 Tamże, s. 46. 
tuacja obarczenia odpowiedzialnością. Z drugiej strony jednak powstaje tutaj zaufanie oraz pochodne od niego zjawisko, czyli więź.

Ricœur zwraca uwagę na różnice w pojmowaniu odpowiedzialności przed zajściem czynu i po zajściu czynu. Odpowiedzialność pierwsza zwraca się ku przyszłości, zaś odpowiedzialność drugiego rodzaju odnosi się już tylko do przeszłości i jest odbierana jako ograniczona. Rozróżnienie to nie we wszystkich przypadkach daje się jednak zastosować. Jeśli mówimy o odpowiedzialności jako zasadzie, to istnieją sytuacje słabości i tragizmu ludzkich spraw, w których, tak jak w przypadku zagrożenia środowiska naturalnego, odpowiedzialność to „nakaz, który wymaga od nas działania w taki sposób, aby ludzkość istniała jeszcze po nas, kieruje się ku przyszłości równie rozległej, jak odległe są skutki naszych technologicznych przedsięwzięć..."11. Występuje przemiana skutków następstw przeszłości w przyszłość.

Nakaz i zaufanie, które się tutaj obserwuje, są dwoistymi znakami ze strony słabego. Jego słabość coś nam nakazuje, a jednocześnie słaby, jako potrzebujący opieki, okazuje ufność w to, że otrzyma pomoc i sam nas wzywa do działania w zaufaniu. Słabość kogoś słabego rodzi w nas reakcję uczuciową i sprawia, że czujemy się odpowiedzialni i że czujemy się powołani do odpowiedzialności. Ricœur broni się przed wejściem w nic niewnoszącą - jak uważa - dyskusję na temat tego, co jest pierwsze - „czy zdolność określenia siebie samego jako odpowiedzialnego autora swych czynów, czy wezwanie ze strony kogoś słabszego". Postuluje natomiast wzajemne poznanie skutkujące tym, że słaby obcy przestaje być obcym i staje się w wyniku zaufania i uczucia bliźnim. Ricœur podkreśla, że wszyscy jesteśmy podobni do siebie jako ludzie, a to, kto jest w danych okolicznościach silniejszy bądź słabszy (i pod jakim względem), bywa względne i zmienne.

Wewnętrzną relację między słabością i odpowiedzialnością widzi też autor na arenie działań politycznych. Zauważa kilka istotnych sprzeczności rodzących napięcie i konflikt. Tkwią one w samym rdzeniu działania politycznego, czyli w trójstronnej i pełnej konfliktu relacji: społeczeństwo polityczne - społeczeństwo obywatelskie - władza. Tu Ricœur widzi pierwszy rodzaj słabości „domagający się” odpowiedzialności. Słabością tą jest usankcjonowana prawem władza państwa, które odbiera władzę swoim obywatelom. Ta władza jest racjonalizo-

11 Tamże, s. 47. 
wana, bo zgodna z konstytucją, a jednak nigdy nie jest w pełni usprawiedliwiona, domagając się odnawiania społecznego mandatu polegającego na odpowiedzialnym postępowaniu rządu.

Drugi rodzaj słabości areny politycznej widzi autor na styku racjonalnej władzy i wspólnoty jej podległej. Społeczeństwo polityczne nie jest w tej relacji społeczeństwem obywatelskim. Wola życia razem we wspólnocie społecznej jest tłumiona poprzez hierarchię władzy i racjonalizowanie się instytucji państwowej i tym samym zanikają więź i współdziałanie na rzecz uległości wobec władzy ${ }^{12}$. Uległość zaś jest zaprzeczeniem odpowiedzialności, i to po obu stronach relacji władza - społeczeństwo.

Paul Ricœur w samym charakterze nowoczesnego państwa demokratycznego zauważa kolejny, paradoksalny rodzaj słabości i podkreśla, że państwo demokratyczne jest dla niego miejscem, w którym więź zaufania między wybranym delegatem a jego elektoratem szybko się gubi w układzie działania fikcyjnej umowy o przedstawicielstwo. Staje się ona fikcją, gdy zanika codzienny kontakt posła z wyborcą, niemniej jednak już w samą ideę reprezentacji, czyli „delegowania" władzy przez wyborcę i złożenia jej w ręce posła, wpisana jest podległość i pewnego rodzaju zapowiedź zrzeczenia się części odpowiedzialności.

Inny przejaw słabości w działaniach politycznych mieszczący się w przedstawianiu paradoksów polityki to, według Ricœura, język polityczny, „który ze względu na swoją przynależność do retoryki musi oscylować pomiędzy racjonalną argumentacją i sofizmatem, oddziałującym przez uwodzenie albo, co gorsza, zastraszenie". Przy tej okazji podkreśla on znaczenie i rolę odpowiedzialności intelektualistów, którzy mają za zadanie wyjaśniać retorykę języka politycznego, a także przedstawiać ją w języku ogólnym, aby społeczeństwo obywatelskie nie oddalało się zbytnio od wytworów własnych decyzji. Ricœur uważa, że znacznie ważniejsza jest jednak przede wszystkim odpowiedzialność każdego indywidualnego obywatela.

Powinien on wiedzieć, że wielkie państwo jest słabe, że opiera się ono na związkach powierniczych, powinien czuć się odpowiedzialnym przede wszystkim za poziomą więź ustanowioną przez chęć życia razem, krótko mówiąc, powinien łączyć dobro ogółu z dynamizmem wspólnotowego życia, wewnątrz którego odradza się wola życia razem ${ }^{13}$.

\footnotetext{
12 Pomaga w tym i trzyma ster sama biurokracja.

13 P. Ricœur, Filozofia osoby, dz. cyt., s. 52.
} 
Odpowiedzialność przyjmuje u Ricœura jeszcze inną postać, mianowicie postać pochodzącą ze sfery znacznie szerszej i przez to mniej wyraziście doświadczanej niż omawiane poprzednio, czyli z dziedziny języka ponadnarodowego w integrującej się Europie. Zamysł wspólnego języka jako formy integracyjnej jest nazwany przez Ricœura (kolejną) słabością. Należy ona tym razem do społeczności międzynarodowej. Postulat modelowego przekładu języków byłby przejawem odpowiedzialności „za mowę w sytuacji rozłamu języków”. Sądzę, że wątek retoryki i języka polityki europejskiej staje się coraz bardziej aktualny w kontekście Unii Europejskiej.

W swojej książce Paul Ricœur twierdzi, że im bardziej świat się racjonalizuje, tym bardziej polityka staje się zbędna. Oddając władze poszczególnym kompetentnym specjalistom, działania czysto polityczne stają się zbędne, przez co władza państwa nad obywatelami ma coraz mniejszą legitymację. Możemy postawić tu pytanie, czy w wyniku takiego procesu okaże się, że instytucja państwa jest zbędna. W pewnym sensie Ricœur antycypuje współczesne dyskusje o „postpolityczności”.

\section{Podsumowanie}

W początkowej części eseju przedstawiliśmy krótki zarys rozwoju myśli na temat odpowiedzialności, począwszy od wybranych fragmentów z Biblii, które staraliśmy się uszeregować według zaobserwowanych tam typów odpowiedzialności. Typy te odpowiadają mniej więcej współczesnym rozumieniom znaczenia tego pojęcia. Wspomnieliśmy o tym podczas przeglądu historii pojęcia odpowiedzialności w prawodawstwie i naukach prawnych, które ostatnio łączą ze sobą różne prądy intelektualne i moralne, aby doskonalić samo prawodawstwo.

Następnie zarysowaliśmy koncepcję odpowiedzialności według Ingardena, w której podnosi się kwestię znaczenia wartości w odczuwaniu i rozumieniu odpowiedzialności.

Część druga eseju poświęcona była charakterystycznemu ujęciu problemu odpowiedzialności będącego w ścisłym związku ze słabością jako legitymizacją władzy, której autorem jest Paul Ricœur.

Własne przemyślenia doprowadzają nas do kilku uogólnień i pytań. A zatem bez względu na pochodzenie pojęcia odpowiedzialności istnieje na pewno odpowiedzialność całkowita, czyli moralno-prawna - za świadome i dobrowolnie 
dokonane czyny, oraz węższa odpowiedzialność prawna - za czyny zabronione oraz stany rzeczy będące konsekwencjami działań nieumyślnych. Odczuwamy i formalnie przyjmujemy odpowiedzialność osobistą - w ramach biurokratycznych struktur i przepisów. Zdarza się wystąpienie odpowiedzialności honorowej - za złe czyny oraz zaniechania innych, wolnych i pełnoprawnych podmiotów. Taka odpowiedzialność ma charakter ściśle etyczny, gdyż jej źródłem jest niezgoda na zło jako takie, nie zaś konkretnie podjęte zobowiązanie. Osobną kwestią byłaby odpowiedzialność intelektualna, a więc odpowiedzialność za słowa, a w tym zwłaszcza za głoszone przekonania (na przykład polityczne), które mogą się stać pobudką do różnych kontrowersyjnych działań.

Na koniec chcielibyśmy zwrócić uwagę na dość rozpowszechnione zjawisko unikania odpowiedzialności. Posłużymy się tu przykładem schematów i struktur biurokratycznych, w których to sama biurokracja wyznacza nam metody postępowania i z nich „rozlicza”. Tu właśnie otwiera się pole do unikania odpowiedzialności jednostkowej, a tym bardziej odpowiedzialności instytucjonalnej. Przekształcanie się autentycznych relacji międzyludzkich w sformalizowane procedury służy wprawdzie budowaniu państwa prawa, ale ceną za praworządność bywa rozmycie odpowiedzialności i bezduszność w działaniu instytucji. To zaś prowadzi do podkopania zaufania między rządzącymi rządzonymi. A bez zaufania nie ma relacji opartych na poczuciu odpowiedzialności.

\section{Bibliografia}

Biblia Tysiąclecia, Poznań 2003.

Hart H., Pojęcie prawa, tłum. J. Woleński, Warszawa 1998.

Ingarden R., Ksiq̨żeczka o człowieku, Kraków 1987.

Kant I., Uzasadnienie metafizyki moralności, tłum. M. Wartenberg, Warszawa 1984.

Ricœur P., Filozofia osoby, tłum. M. Frankiewicz, Kraków 1992. 